\title{
Pittosporum undulatum Vent.: subsidies to the control and management ${ }^{(1)}$
}

\author{
RAQUEL REJANE BONATO NEGRELLE (2), ERICA COSTA MIELKE(3), \\ FRANCINE LORENA CUQUEL ${ }^{(2)}$, EDWIN ERNESTO PULIDO ${ }^{(4)}$
}

\begin{abstract}
Pittosporum undulatum (Australian cheesewood) is considered an ornamental species with high invasive potential, due to its strong adaptation capacity to colonize different habitats. Aiming to support controlling management actions, a review of its botanical, ecological, ethnobotanical and silvicultural aspects are presented. Control programs should include this type of information to ensure that the limited resources devoted to this issue will be efficiently allocated. It is important to address holistically the causes of the invasion, particularly the role of the original structure and functional changes imposed on ecosystems and their processes, since colonization by invasive species.
\end{abstract}

Keywords: alien invasive species; sweet pittosporum.

\section{RESUMO}

Pittosporum undulatum Vent.: subsídios ao controle e manejo

Pittosporum undulatum (pau-incenso) é considerada espécie ornamental de elevado potencial invasor, dada sua grande capacidade de adaptação para colonizar habitats diversos. Visando a subsidiar ações de manejo para o seu controle, apresenta-se revisão sobre aspectos botânicos, ecológicos, etnobotânicos e silviculturais relacionados a esta espécie. Programas de controle devem incluir este tipo de informações de modo a assegurar que os limitados recursos destinados a esta questão sejam eficazmente alocados. Ressalta-se a importância de abordar de forma holística as causas da invasão, particularmente o papel da estrutura original e modificações funcionais impostas sobre os ecossistemas e seus processos, desde a colonização pela espécie invasora.

Palavras-chave: espécie exótica invasora; pau incenso.

\section{INTRODUCTION}

Pittosporum undulatum Vent. (Australian cheesewood) is a native tree from Australia, belonging to the Pittosporaceae family (LORENZI et al., 2003). The pleasant odor from its flowers, as well as the intensity of the yellow-orange coloration of its fruits that attract and feed birds, most likely motivated its use in urban areas as an ornamental plant (BINGGELI and GOODLAND, 1998). However, Pittosporum undulatum is considered to have a high invading potential in the face of successful processes of dispersal, competition and persistence of their populations (GOODLAND and HEALEY, 1996). In Brazil, there is a record of its occurrence as an invasive exotic species (IES) in several Southern and Southeastern locations (BLUM et al., 2005; INSTITUTO HÓRUS, 2005; PARANÁ, 2007; SANTA CATARINA, 2010) as well as Midwest (SANTANA and ENCINAS, 2008).

As an exotic species is one that is outside its natural range, and when it threatens native species, as well as human life, ecosystems or habitats, it is known as an alien invasive species (AIS) (BRASIL, 2009). The adaptation to the environment conditions in which it was inserted, absence of predators, and natural environment degradation are the main factors that cause an exotic species to become invasive, competing with native species for resources - such as territory, water, food causing a great impact to the environment (GLEADOW and ASHTON, 1981; MOREIRA et al., 2003).

The invasion of exotic species is recognized as the second most threatening cause of global diversity, occurring soon after loss of habitat and fragmentation of landscapes (WALKER and STEFEN, 1997; MATTHEWS and BOLZANI, 2005). Economic loss associated with the presence of invasive species is also a serious concern in several parts of the world (PIMENTEL et al., 2001). Costs resulting from the invasive alien species presence in agricultural crops, pasture and forest areas are significant. According to some estimates, they may be costing to the global economy US\$1.4 trillion or more. Global losses due to exotic species could reach more than US $\$ 12$ billion, only in relation to eight major crops in Africa. Management for the invasive alien species control is therefore perhaps the greatest conservation challenge to be faced in the coming decades (BRASIL, 2009; SECRETARIADO CBD, 2010).

\footnotetext{
DOI: http://dx.doi.org/10.14295/oh.v24i4.1457

(1) Received in 28/08/2018 and accepted in 24/09/2018

(2) Universidade Federal do Paraná (UFPR), Curitiba-PR, Brazil * corresponding author: negrelle@ufpr.br

(3) Prefeitura Municipal de Curitiba, Secretaria Municipal de Meio Ambiente, Curitiba-PR, Brazil

(4) Universidad de Cundinamarca, Facultad de Ciencias Agropecuarias - Ingeniería, Agronómica, Fusagasugá-Cundinamarca, Colômbia.

Licensed by CC BY 4.0
} 
There are different methods for controlling invasive alien species, grouped into four main categories: mechanical, chemical, biological and environmental. Solutions to biological invasion problems in general are mix use of these different methods, because each situation is different, and each species reacts differently to the control. Therefore, there is no ready income and it is necessary to understand the environmental variables and the species behavior in question to define the most appropriate method (INSTITUTO HÓRUS, 2011).

In this context and aiming to subsidize management actions for its control, a review is presented on botanical, ecological, ethnobotanical and silvicultural aspects related to this species.

\section{BOTANICAL ASPECTS}

\section{Botanical classification}

Pittosporum is the greatest diversity genre among the Pittosporaceae, comprising approximately 200 species. Probably from the Gondwana period, it is distributed in a wide area that includes Australia, East Asia, Oceania and parts of Africa, occurring mainly in coastal regions, red and yellow alluvial and podzolic soils (GLEADOW and ASHTON, 1981). The name of this genre was set up from the Greek words "pitta" and "sporum" (seed), referring to the resinous and adherent covering of its seeds.

Pittosporum undulatum was described in 1802 by the Frenchman Étienne-Pierre Ventenat (1757-1808), professor, botanist and librarian of the Pantheon of Paris and responsible for the gardens of the Malmaison Castle. However, what definitely set him apart as one of the most prominent French botanists was the publication of magnificently illustrated works, including Description des plantes nouvelles et peu connues, cultivées dans le jardin de J.-M. Cels where is presented the Pittosporum undulatum. The specific epithet originates from the Latin term unda (wave), referring to the corrugated border that is characteristic of this species leaf (ANPSA, 2017). Taxonomically, Pittosporum undulatum is a well-defined taxon, it is possible that it is a hybrid from the Pittosporum bicolor and maybe from Pittosporum revolutum as well (BINGGELI and GOODLAND, 1998).

Botanically (TROPICOS, 2011), this species is categorized as:

Class: Equisetopsida C. Agardh

Subclass: Magnoliidae Novák ex Takht.

Superorder: Asteranae Takht.

Order: Apiales Nakai

Family: Pittosporaceae R. Br.

Genre: Pittosporum Banks ex Gaertn.

Pittosporum undulatum Vent. does not have synonyms (TROPICOS, 2011).

This species is recognized by different popular names in the different regions where it occurs (LORENZI et al., 2003), namely: Brazil: incense stick or incense. Azores: pitosporo-ondulado, incense or beech tree. Asia and Oceania: Australian cheesewood, mock orange, native daphne, orange pittosporum, sweet pittosporum, Victorian box, Victorian laurel, wild coffee (GOODLAND and HEALEY, 1996).

\section{Botanical characterization}

Pittosporum undulatum is a perennial tree up to $30 \mathrm{~m}$ in height (BINGGELI and GOODLAND, 1998) and $7 \mathrm{~m}$ in diameter of pyramidal canopy, trunk with smooth grayish bark (ANPSA, 2017). In drier regions, it may not exceed the shrub size, between 2 and $3 \mathrm{~m}$ high (GOODLAND and HEALEY, 1996). In Brazil, representatives of this species were registered from 7 to $10 \mathrm{~m}$ in height (LORENZI et al., 2003). Their leaves are perennials, and characteristically wavy at the edges, agglomerated at the ends of the branches, simple, petiolate, arranged in spiral, oval-elongated or lanceolate blades, of acute apex, subcoriaceous, aromatic, dark green and shiny on the upper face, with 7 to $15 \mathrm{~cm}$ in length, and about $2 \mathrm{~cm}$ in width (GOODLAND and HEALEY, 1996; LORENZI et al., 2003) with resin channels (FERREIRA et al., 2006). Its inflorescence is terminal, with white flowers with yellow center, $1.5 \mathrm{~cm}$ long, very fragrant (LORENZI et al., 2003). Its fruits are loculcidal capsule type (12 $\mathrm{cm}$ in diameter) decanter bivalvar, globular yellow or orange, aromatic, with exocarp and endocarp uniseriate. The external mesocarp is parenchymatic with vascular bundles associated with resin canals and idioblasts with drusen. In the mature fruit, the canals become larger and the sclereids, previously associated only with the vascular bundles, are distributed throughout the mesocarp (FERREIRA et al., 2006). The ovule is anatropous and unitegument. Seeds, usually 20 per fruit, are rheinorm, albuminous, with a smooth, shiny forehead, reddish-brown, rounded whitish, micropyle and raffia fibers, approximately $4.0-5.0 \mathrm{~mm} \times 3.0-4.0 \mathrm{~mm}$ wide, resinous/sticky tegument. The mature seed is nitegumentate and albuminous, with exotesta, mesotesta and endotesta. The embryo is spatulate and presents a tiny hypocotylradicular axis located at one end of the seed, oblique to its main axis (LORENZI et al., 2003).

\section{Distribution}

Pittosporum undulatum originates from the wetlands of Australia's eastern coast (GOODLAND and HEALEY, 1996), but has had its deployment area drastically expanded after European colonization. It has been registered in the United States of America, Mexico, South Africa, Caribbean (Jamaica, Puerto Rico), Central America (Guatemala), South America (Colombia, Ecuador, Bolivia and Brazil) (GOODLAND and HEALEY 1997; BELLINGHAM et al., 2005) besides Spain (PAIVA, 1997), and Portugal (MARCHANTE et al., 2008). It occurs in a wide variety of environments, including Tropical Forest, Wet or Dry Sclerophyll Forest as well as Savannah (BINGGELI and GOODLAND, 1998). In Brazil, there is a record of its occurrence as an invasive exotic species (IES) in several southern and southeastern locations (BLUM et al., 2005; 
INSTITUTO HÓRUS, 2005; PARANÁ, 2007; SANTA CATARINA, 2010) as well as midwest (SANTANA e ENCINAS, 2008), including important conservation units (MIELKE et al., 2010).

\section{ECOLOGICAL ASPECTS}

Pittosporum undulatum life cycle and longevity are scarcely known (GOODLAND and HEALEY, 1996). It is an extremely fast-growing tree, rapidly colonizing deforested areas in various regions where it was introduced as Caribbean, Hawaii, Azores, Madeira Island and southern Brazil. Even in the region of Sydney (Australia), where it is native, Pittosporum undulatum expanded to previously unoccupied soils and plant formations, eliminating by competition and shading many of the naturally occurring species in these habitats (ANPSA, 2017), including native eucalyptus forests (GLEADOW and ASHTON, 1981). Introduced in Jamaica in 1883 at the Botanical Garden of Cinchona, this species quickly became dominant in many forested areas of this region (BINGGELI and GOODLAND, 1998). In the Azores Archipelago, it was introduced more than 150 years ago to constitute hedges. It completely invaded the entire area between sea level and $600 \mathrm{~m}$ high, profoundly altering the appearance of the Azorean landscapes (BATISTA et al., 1998; CORDEIRO et al., 2005).

In Hawaii and other Pacific Islands Pittosporum undulatum was considered as an invasive species with high capacity to cause ecological and economic damages (DAEHLER et al., 2004). Similar pattern occurred in forested areas and riparian forest in Cape Province (South Africa) (BINGGELI and GOODLAND, 1998). This species was officially considered an invasive plant in Portugal (Decree-Law no. 565/99). However, it is in the Atlantic archipelagos and especially in the Azores (where it is present in all the islands) that its harmfulness is more noticeable. Its presence has also been registered in conservation units, such as the Parque da Pena (Sintra) (ALVES et al., 2003).

In Brazil, this species appears as an invasive species in the list generated by the National Survey of Invasive Species (BRASIL, 2006), with occurrence records as invasive in of Rio Grande do Sul, Santa Catarina, and Paraná States (BLUM et al., 2005; INSTITUTO HÓRUS, 2005; SANTA CATARINA, 2010; BLUM et al., 2005). In Rio Grande do Sul State, this species has invaded Permanent Preservation Areas slope, and its population growth is considered a limiting factor to the natural succession cycles (KARAM et al., 2007).

Adults of this species are generally not shade tolerant (GLEADOW, 1983). However, there is a record of its occurrence in shaded environments of the forest understory (BLUM et al., 2005). When solar radiation is between $4-8 \%$ and even below $2 \%$, it is already observed the presence of Pittosporum undulatum (GLEADOW and ASHTON, 1981). The vigorous growth of dense shade seedlings may be related to the greater drought tolerance of the shade seedlings (GLEADOW and ROWAN, 1982) or greater competitive capacity of the seedlings (GLEADOW, 1982). However, recruitment may become more intense with the increase in light incidence, caused by the opening of clearings, reaching 5000 seedlings per $\mathrm{m}^{2}$ (BINGGELI and GOODLAND, 1998).

Pittosporum undulatum seedlings are highly tolerant to drought when in moderately low temperature $\left(21.4^{\circ} \mathrm{C}\right.$ day / $17.8^{\circ} \mathrm{C}$ night compared with $27.4{ }^{\circ} \mathrm{C}$ day/ $23.9{ }^{\circ} \mathrm{C}$ night) and well shaded environment. Cultivated well-watered seedlings showed relative growth rates, and higher net assimilation rates when grown under higher temperatures, and higher light intensities. Cultivated seedlings were leafier when cultivated under low light resulting in a larger specific leaf area, as well as a greater proportion of leaf area in relation to the root. The adverse effects of higher light intensities and temperature on drought tolerance by cultivated seedlings of Pittosporum undulatun support the hypothesis that the survival of the seedlings in their first year is mainly dependent on the microclimate where they are (GLEADOW and ROWAN, 1982).

Ecological analysis of the wood provided evidences that Pittosporum undulatun has a greater investment in xylem safety than in water transport efficiency. The values of the ecological indices observed are related to plants adapted to conditions of lower water availability (LONGUI et al., 2011).

Pittosporum undulatum has an opportunistic ecological behavior, taking advantage of the environmental changes resulting from human activity, such as the fragmentation of habitats, or changes in nutritional patterns of the soil and the suppression of forest fires. Unlike many competing plants, Pittosporum undulatum is favored by the existence of high levels of nutrients in the soil and its seeds germinate without the need for fire. Its leaves contain toxins that can inhibit the growth of other plants (BUSHCARE, 2003). It invades native forest areas and can shade native plants (ANPSA, 2017). However, the most likely explanation for the successful invasion of Pittosporum undulatum would be the competitive ability of this species (TUNBRIDGE et al., 2000). The main characteristics of Pittosporum undulatum that favor its establishment are; high germination rates (MULLET, 1999a, MULLET, 1999b), high adaptation capacity and plasticity in front of different types of soil (MULLET, 1999b), high yield of seedlings (37,500 seeds/ ind.), efficient ornithocoric dispersion (GOODLAND and HEALEY, 1997b) and favored growth and regrowth capacity in the opening of clearings (ROSE, 1997).

This species is considered to be ecologically important due to the environmental degradation it causes, mainly by reducing native forest areas (MULLET, 1999b). It has an enormous capacity to attract pollinators, which reduces the availability of pollinating agents in native plants and maximizes, at the same time, its production of fruits and seeds (GOODLAND and HEALEY, 1997a). According to Goodland and Healey (1997b) Pittosporum undulatum stem, due to its smooth bark, has a low capacity to house epiphytic plants, reducing their diversity in the invaded environment. 


\section{Phenology}

Pittosporum undulatum flowering begins at 5 years of age (BINGGELI and GOODLAND, 1998). Its reproductive activity was observed in small sprouts ( $2 \mathrm{~m}$ high) (BLUM et al., 2005). In the southern hemisphere its flowering occurs between September and November and fruiting between May and July. In mid-October fruits open and release the seeds (INSTITUTO HÓRUS, 2011).

\section{Biology of Reproduction}

Pittosporum undulatum flowers sexual expression is quite variable, but flowers are usually unisexual. Insects, mainly bees, pollinate their flowers (Goodland and Healey, 1996). Their capsules take about six months to mature and generally contain from 20 to 40 seeds (BINGGELI e GOODLAND, 1998). Its seed production is high (MULLET, 1999b) and can reach 37.500 seeds/plant (GOODLAND and HEALEY, 1997a). It is unusual for their seeds not to be stored in the soil at least from one year to the next, potentially forming a seed bank (GLEADOW and ASHTON, 1981; GLEADOW, 1982).

\section{Dispersion}

The dispersion of Pittosporum undulatum seeds may occur by hydrochory and zoocchory (BLUM et al., 2005; MULLET, 1999b), especially ornithochory (GOODLAND and HEALEY, 1997b). In some cases, dispersion may be favored by the introduction of exotic birdlife (GLEADOW, 1982). Many herbivores do not appreciate the Pittosporum undulatum resinous seeds. However; these are food sources for some New Zealand animals such as the parrotKea (Nestor notabilis) as well as other European generalist frugivorous birds including Pied Currawongs (Strepera graculina), European Blackbirds (Turdus merula), Satin Bowerbirds (Ptilonrhynchus violaceus) Silvereyes (Zosterops lateralis) and Red whiskered Bulbuls (Pycnonotus jocosus) (COOPER, 1956, GLEADOW 1982, BUCHANAN, 1989, MULLETT, 1999a). In Brazil, the fruits of this species are also reported as a food source for the avifauna, especially for several species of thrush (Turdus spp.) (FONSECA and ANTUNES, 2007). However, it is unanimous that the main vector of its dispersion is anthropic, when planting this species for ornamental purposes (GLEADOW and ASHTON, 1981, GOODLAND and HEALEY, 1996) or for curtain or vegetable curtain composition (MEDEIROS et al., 2003).

\section{TOXICITY AND BIOACTIVITY}

Pittosporum undulatum contains moderately toxic elements. These elements are poorly absorbed by the human organism, which determines a low incidence of intoxication problems associated with this species (GARDENBREIZH, 2011). According to ASPCA (2017), Pittosporum undulatum is not toxic to cats, dogs and horses, but if accidentally ingested by these animals can cause colic and gastrointestinal distress.

It contains saponins and is therefore used in fish as fish poisons (PLANTAS DO FUTURO, 2003).
According to USDA (2004) Pittosporum undulatum species representatives are a source of leucoanthocyanin, also known as proanthocyanidin (PA or PAC). Leucoanthocyanins are a family of natural polyphenols belonging to the class of bioflavonoids whose chemical structure is based on the flavilium nucleus, which consists of three phenolic rings, in this being case the third ring a heterocyclic pyran, called the flavana nucleus (MACHADO et al., 2008). Its components are strong hydrosoluble antioxidant agents with extensive clinical applications including cancer prevention, anti-inflammatory action and reduced cardiovascular mortality risk (COS et al., 2004).

From the leaves, as well as flowers and fruits, essential oil can be extracted (MEDEIROS et al., 2003), which has high anticoagulant activity (MEDEIROS et al., 2000). The essential oil from Pittosporum undulatum' leaves of present's microbiological activity against Staphylococcus aureus and S. epidermis (MEDEIROS et al., 2003). The distinct components of this essential oil showed different spectra of inhibition on the growth of Aspergillus flavus, but all were able to inhibit the production of aflatoxin $\mathrm{B}_{1}$ (MEDEIROS et al., 2011).

In Brazil, as well as in other places where it is found, it is considered quite ornamental, being used in landscaping, gardening and urban planting (JOLY, 1993; LORENZI et al., 2003). By the fragrance of their flowers, they attract insects, especially bees that feed on the abundant nectar (BINGGELI and GOODLAND, 1998). Its wood produces firewood and charcoal of good quality, besides the use for carpentry or carpentry (BATISTA et al., 1998).

Outside of Brazil, there is a record of its employment for golf club management (PLANTAS DO FUTURO, 2003). In Azores and Jamaica, leaves have been used for seasonal feeding of cattle and goats during droughts (GOODLAND and HEALEY, 1996; OLIVEIRA and BORBA, 1999), which is quite surprising considering their coriaceous leaves, with levels high levels of secondary compounds, including sapogenins (HIGUCHI et al., 1983). The vegetal material presents potential to be used in composting for horticulture (OLIVEIRA and BORBA, 1999). In Australia, fruits and seeds have been popularly cited for bronchitis, malaria, wounds and stomach disorders treatments (COOPER, 1956).

\section{CONTROL AND MANAGEMENT}

Pittosporum undulatum presents intense regeneration of trunks and roots, which makes mechanical removal laborious and expensive. The physical removal of seedlings is relatively easy, but this process in more developed individuals depends on the adequate removal of the vegetal remains due to their significant regrowth capacity (INSTITUTO HÓRUS, 2011; STAR et al., 2005). The removal of the bark is effective in preventing regrowth only when applied radically from $30 \mathrm{~cm}$ from the ground (GOODLAND and HEALEY, 1997a). The incineration of the vegetable remains $\left(180{ }^{\circ} \mathrm{C}\right.$ for $5-10$ minutes in an appropriate furnace) promotes the total burning of these. However, $20 \%$ of adult trees re- 
emerged after 6 months of having undergone field fire (GLEADOW and NARAYAN, 2005), since fire kills only the basal shoots of the trunk, being inefficient as a measure of control or eradication, especially in urban or periurban environment (MULLET, 1999a)

There is a reasonable amount of biological knowledge about Pittosporum undulatum as well as of its natural enemies in its region of origin, being the species susceptible to aphids, mites, cochineals, some foliar fungi, root nematodes, galls and chancres (BRICKELL and ZUK, 1997). However, biological control involving either direct manipulation of established populations of natural enemies through mass production or colonization; either by habitat manipulation to encourage populations of natural enemies that kill the invader or drastically reduce their competitive capacity, is not yet available in any of the places where this species has been detected as invasive (GOODLAND and HEALEY, 1996). Classical biological control programs of exotic invasive plants, such as Pittosporum undulatum, are also non-existent in Brazil, although there are Brazilian researchers working in the area, against this process, subsidizing international cooperation programs, with focus in native plants that have become weeds in other regions of the world (NACHTIGAL, 2009). It should be noted, however, that biological control when developed should be applied with extreme caution so as not to promote damage or side effects on the native species that cohabit with the exotic species (STAR et al., 2005).

In this way, chemical control is the most indicated against Pittosporum undulatum (GOODLAND and HEALEY, 1997a, INSITUTO HÓRUS, 2011). In this case, the treatment consists in making successive cuts and interspersed with a hatchet at the base of the trunk, with a difference of $10 \mathrm{~cm}$ in height, around the whole trunk. Dilute glyphosate $2 \%$ in water should be applied to each cut as it is done one by one. The shorter time between cutting and the application of the product, the greater the efficiency of the results. In case of removal of the trees for use or sale of the wood, the chemical control is fundamental and must be performed at the time of cutting. Trees should be cut close to the ground. It is necessary the direct application of herbicide in the stumps to avoid the regrowth generation, which makes difficult and onerous the posterior control. In order to do that, the herbicide needs to be applied immediately after cutting, in a matter of seconds, to have greater efficiency. The most used product is a selective systemic herbicide of foliar application in total area (Garlon $480 \mathrm{BrC}$ ), product based on triclopyr, at a concentration of $80 \%$ diluted in diesel oil. In the absence of Garlon, another selective-action systemic herbicide is used (Tordon $($ ) ), consisting of triethanolamine salt 2,4-d in combination with picolinic acid derivative and 2,4-d phenoxyacetic acid group at a concentration of $7 \%$ diluted in water. There are serious concerns about the environmental impact and persistence of Tordon (C) Picloram, an active ingredient of this herbicide, was still present in the soil twelve months after application in a tropical forest in Puerto Rico (reaching a maximum of 0.05 ppm of 12-30 cm of depth) (DOWLER and TSCHIRLEY,
1970). Glyphosate appears to be effective and has very low toxicity for humans (GROSSBARD and ATKINSON, 1984), however; there seems to be little advantage in using Tordon ${ }^{\circledR}$, in addition to its low cost. If after the application of the herbicide there is still sprouting, the shoots should be removed when they reach 15 to $30 \mathrm{~cm}$ in height by spraying on the leaves with glyphosate diluted in $2 \%$ water. The application of the herbicide should be carried out with safety equipment, with good performance spray and precision, without leaks, and on days without wind to avoid parallel impacts on other species, soil or water. The treatment must be repeated each time the shoots reach the indicated height. Preliminary work suggests a tendency of elimination of the plants with four successive applications in the regrowth. As already mentioned, all the plant material removed should be appropriately packed in a way to avoid regrowth. The alternatives are composting or incineration (BATISTA et al., 1998). It is important to note that although these herbicides represent a significant environmental impact, the alternative of continuing the invasion could have a significant impact on the environment (GOODLAND and HEALEY, 1996).

Additionally, an appropriate Pittosporum undulatum control could be done managing with the environmental conditions favoring restoration to give it greater resistance to invasion processes. When the invasion exerts a great dominance pressure on the environment, it is common that restoration processes are necessary, involving native species replanting, soils decomposition, native species sowing for soil cover and other techniques. These methods aim only to return to the environment a condition more favorable to recolonization by native species of the ecosystem and thus to hinder the entry of invasive alien species (INSTITUTO HÓRUS, 2011). However, this process is still embryonic in most places where there is occurrence of Pittosporum undulatum invasion, including Brazil.

Although controlling invasive plants is a serious environmental issue, it does not seem to receive enough attention in environmental management agendas globally. There is an urgent need to perform public education campaigns to enhance the political and environmental insertion of this issue and to encourage more responsible agricultural and urban practices, regarding the prevention of invasive alien species entrance (MULLET, 1999a). Pittosporum undulatum is recognized as a high invasive potential species (CARR et al., 1992), and the propagation of this species in areas outside its natural area is a potentially threatening process for the environment. However, this species is still commercially available from nurseries and continues being inserted in gardens and urban and periurban parks, where an expressive set of dispersers favors its spread in the remnants of native vegetation (MULLET, 1999a; MIELKE, 2010).

Attempts to control invasive plants will have little success in the long run, without proper management of the source populations and their dispersing agents. Control programs should include information on the biological and ecological characteristics of the target species in order to ensure that the limited resources devoted to this issue are 
effectively allocated (MULLET, 1999a). The importance of holistically addressing the causes of invasion, particularly the role of the original structure and functional modifications imposed on the ecosystems and their processes, from colonization by the invasive species, is emphasized. Although these underlying causes of invasion are perhaps difficult to quantify, this approach represents a new challenge for the management of invasive plants and requires knowledge and research at the interdisciplinary level (HOBBS and HUMPHRIES, 1995).

\section{CONCLUSIONS}

Pittosporum undulatum is an extremely fast-growing tree, rapidly colonizing deforested areas in various regions where it was introduced. As invasive species, it is considered ecologically important due to the environmental degradation it causes, mainly by reducing native forest areas. Actions for its control and management should consider that it presents intense regeneration of trunks and roots, which makes mechanical removal laborious and expensive. The physical removal of seedlings is relatively easy, but this process in more developed individuals depends on the adequate removal of the vegetal remains due to their significant regrowth capacity. Chemical control applied on successive cuts, around the whole trunk, is fundamental and must be performed when cutting adult individuals.

\section{AUTHORS CONTRIBUTIONS}

R.R.B.N. D0000-0003-3725-3426: Idealization of research, collection, analysis and interpretation of data, writing of the article. E.C.M. (1)0000-0002-2883-9321: data collection, analysis and interpretation, writing support. F.L.C. (D0000-0002-3026-2058: collection, analysis and interpretation of data, writing support. E.E.P. (10000-0001-7248-6677: collection, analysis and interpretation of data, writing support.

\section{REFERENCES}

ANPSA. Australian Native Plants Society - Pittosporum undulatum. Available in: <http://anpsa.org.au/p-und.html > Access on January 10 2017.

ASPCA. The American Society for the Prevention of Cruelty to Animals (ASPCA). Available in: $<$ http://aspca. org $>$ Access on January $10^{\text {th }}, 2017$.

BATISTA, J.G.; BATISTA, E.R.B.; MATEUS F.F. Effectiveness of two biodegradation methods on the physical characteristics of compost for horticulture purposes. Acta Horticulturae, n.517, p.293-302, 1998.

BINGGELI, P.; GOODLAND, T. Pittosporum undulatum Vent. (Pittosporaceae). 1998. Available in: <http:// members.multimania.co.uk/WoodyPlantEcology/docs/ web-sp15.htm $>$ Access on: May $08^{\text {th }} 2017$.
BLUM, C.T.; POSONSKI, M.; HOFFMANN, P. M.; BORGO, M. Espécies vegetais invasoras em comunidades florestais nativas nas margens da represa Vossoroca, Apa de Guaratuba, Paraná, Brasil. Brasília: Ministério do Meio Ambiente, 2005. 15p.

BRASIL. Ministério do Meio Ambiente. Secretaria de Biodiversidade e Florestas. Espécies Exóticas Invasoras: situação brasileira. Brasília: MMA, 2006. 24p.

BRASIL. Ministério do Meio Ambiente. Secretaria de Biodiversidade e Florestas. Comissão Nacional de Biodiversidade. Resolução CONABIO, no. 5, de 21 de outubro de 2009.

BRICKELL, C.; ZUK, J.D. The American Horticultural Society A-Z encyclopedia of garden plants. NY: DK Publishing, 1997. 1004p.

BUCHANAN, R.A. Pied currawongs (Strepera graculina): their diet, and role in weed dispersal in suburban Sydney, New South Wales. Proceedings of the Linnaean Society of New South Wales, n.111, p.241-55, 1989.

CARR, G.W.; YUGOVIC, J.V.; ROBINSON, K.E. Environmental weed invasions in Victoria: conservation and management implications. Victoria: Department of Conservation and Natural Resources and Ecological Horticulture, 1992. 78p.

COOPER, C.R. The Australian and New Zealand species of Pittosporum. Annals of the Missouri Botanical Garden, v.43, n.2, p.87-188, 1956.

CORDEIRO, N.; SILVA, L.; ILLAS, X.; MARTINEZ, A. Distribuição e abundância de Pittopsorum undulatum na Ilha do Pico (Açores). Relatórios e Comunicações do Departamento de Biologia, Açores, v.34, p.235-244, 2005.

COS, P.; BRUYNE, T.; HERMANS, N.; APERS, S.; BERGHE, D.V.; VLIETINCK, A.J. Proanthocyanidins in health care: current and new trends. Current Medicinal Chemistry, v.11, n.10, p.1345-1359, 2004.

DAEHLER, C.C.; DENSLOW, J.S.; ANSARI, S.; KUO, $\mathrm{H}$. A risk-assessment system for screening out invasive pest plants from Hawaii and other Pacific Islands. Conservation Biology, v.18, n.2 p.360, 2004.

DOWLER, C.C.; TSCHIRLEY, F.H. Effects of herbicides on a Puerto Rican rain forest. In: ODUM, H.T; PIGEON, R.F. A Tropical Rainforest. Springfield: USAEC, NTIS, 1987. p. $315-23$. 
FERREIRA, N.J.; SOUSA, I.G.M.; LUÍS, T.C.; CURRAIS, A.J.M.; FIGUEIREDO, A.C.; COSTA, M.M.; LIMA, A.S.B.; SANTOS, P.A.G.; BARROSO, J.G.; PEDRO, L.G. Pittosporum undulatum Vent. grown in Portugal: secretory structures, seasonal variation and enantiomeric composition of its essencial oil. Flavour and Fragrance Journal, v.22, n.1, p.1-9, 2006.

FONSECA, F. Y.; ANTUNES, A. Z. Frugivoria e predação de sementes por aves no Parque Estadual Alberto Löfgren, São Paulo, SP. Revista do Instituto Florestal, v.19, n.2, p.81-91, 2007.

GARDENBREIZH. Base des plantes exotiques, subtropicales et tropicales. Available in: <http:// gardenbreizh.org/modules/gbdb $>$ Access on: September, $20^{\text {th }}, 2011$.

GLEADOW R.M. Invasion by Pittosporum undulatum of the forests of Central Victoria Australia. II dispersal germination and establishment. Australian Journal of Botany, v.30, n.2, p.185-198, 1982.

GLEADOW, R.M.; ASHTON, D.H. Invasion by Pittosporum undulatum of the forests of Central Victoria Australia. I invasion patterns and plant morphology. Australian Journal of Botany, v.29, n.6, p.705-720, 1981.

GLEADOW, R.M.; NARAYAN, I. Temperature thresholds for germination and survival of Pittosporum undulatum: implications for management by fire. Acta Oecologica, v.31, n.2, p.151-157, 2007.

GLEADOW, R.M; ROWAN, K.S. Invasion by Pittosporum undulatum of the forests of Central Victoria Australia III. Effects of temperature and light on growth and drought resistance. Australian Journal of Botany, v.30, n.3, p.347-358, 1982.

GLEADOW, R.M. Invasion by Pittosporum undulatum of the forests of Central Victoria Australia. IV Shade tolerance. Australian Journal of Botany, v.31, n.2, p.151-160, 1983.

GOODLAND, T.; HEALEY, J. R. The invasion of Jamaican rainforests by the Australian tree Pittosporum undulatum. Bangor: University of Wales, 1996. 55p. Available in: <http://www.bangor.ac.uk/ afs101/iwpt/ pittorep.pdf $>$ Access on December, 19 $9^{\text {th }}, 2010$.

GOODLAND, T.; HEALEY, J.R. The control of the Australian tree Pittosporum undulatum in the Blue Mountains of Jamaica. Bangor: University of Wales, 1997(a). 27p. Available in: <http://www.bangor. ac.uk/ afs101/iwpt/control.pdf $>$. Access on: December, $19^{\text {th }}, 2010$.
GOODLAND, T.; HEALEY, J.R. The effect of Pittosporum undulatum on the native vegetation of the Blue Mountains of Jamaica. Bangor: University of Wales, 1997 (b). 41p. Available in: <http://www.bangor. ac.uk/ afs 101/iwpt/effects.pdf $>$ in December, 19 ${ }^{\text {th }}, 2010$.

GROSSBARD, E; ATKINSON, D. The herbicide Glyphosate. London: Butterworths, 1984. 496p.

FUJIOKA, T.; IWAMOTO, M.; KOMORI, T.; KAWASAKI, T.; LASSAK, E. V. Triterpenoid sapogenins from leaves of Pittosporum undulatum. Phytochemistry, v.22, n.5, p.1235-7, 1983.

HOBBS, R.J.; HUMPHRIES, S.E. An integrated approach to the ecology and management of plant invasions. Conservation Biology, v.9, n.4, p.761-70, 1995.

INSTITUTO HÓRUS DE DESENVOLVIMENTO E CONSERVACÇÃO AMBIENTAL. Levantamento de espécies invasoras: resultados preliminares. 2005. Available in: <http://www.institutohorus.org.br/index. php?modulo=inf_ficha_pittosporum_undulatum $>$ Access on: December, $19^{\text {th }}, 2010$.

INSTITUTO HÓRUS DE DESENVOLVIMENTO E CONSERVAÇÃO AMBIENTAL. Métodos de controle de espécies exóticas invasoras. Available in: <www. institutohorus.org.br> Access on: August, 10 ${ }^{\text {th }}, 2011$.

JOLY, A.B. Botânica: introdução à taxonomia vegetal. São Paulo: Companhia Editora Nacional, 1993. p.364-366.

LONGUI, E.L.; ROMEIRO, D.; SILVA, M.T.; RIBEIRO, A.G.; LIMA, T.C.; FLORSHEIM, I.L.; BORGES, S.M. Caracterização do lenho e variação radial de Pittosporum undulatum Vent. (pau-incenso). Hoehnea, v.38, n.1, p.3750, 2011.

LORENZI, H.; SOUZA, H.M.; TORRES, M.A.V.; BACHER, L.B. Árvores Exóticas no Brasil: madereiras, ornamentais e aromáticas. São Paulo: Plantarum, 2003. 368p.

MACHADO, H.; NAGEM, T.J.; PETERS, V.M.; FONSECA, C.S.; OLIVEIRA, T.T. Flavonóides e seu potencial terapêutico. Boletim do Centro de Biologia da Reprodução, v. 27, n.1/2, p. 33-39, 2008.

MATtheWS, S.; BolZANI, G. América do Sul Invadida. A crescente ameaça das espécies exóticas invasoras. Cape Town: GISP, 2005. 80p.

DE MEDEIROS, J.M.; MACEDO, M.; CONTANCIA, J.P.; NGUYEN, C.; CUNNINGHAM, G.; MILES, D.H. Antithrombin activity of medicinal plants of the Azores. Journal of Ethnopharmacology, v.72, p.157-165, 2000. 
MEDEIROS, R.J., CAMPOS, L.B.; MENDONÇA, S.C.; DAVIN, L.B.; LEWIS, N.G. Composition and antimicrobial activity of the essential oils from invasive species of the Azores, Hedychium gardnerianum and Pittosporum undulatum. Phytochemistry, v.64, p.561-565, 2003.

MEDEIROS, R.T.S.; GONCALEZ, E.; FELICIO, R.C.; FELICIO, J; D. Evaluation of antifungal activity of Pittosporum undulatum L. essential oil against Aspergillus flavus and aflatoxin production. Ciência e Agrotecnologia, v.35, n.1, p.71-76, 2011.

MIELKE, E.; CUQUEL, F. L.; NEGRELLE, R. R. B.; PIZZATO, W. Invasive exotic trees in the conservation units in Curitiba, Brazil. Acta Horticulturae, n.881, p.493-497, 2010.

MOREIRA, I.; ALVES, J.; DUARTE, M. C.; MONJARDINO, J. Infestantes ambientais no Parque da Pena (Sintra). Anais do Instituto Superior de Agronomia, v.49, p.271-284, 2003.

MULLETT T.L. Some characteristics of a native environmental weed: Pittosporum undulatum. In: BISHOP, A.C.; BOERSMA, M.; BARNES, C.D. Proceedings of the 12th Australian Weeds Conference. Devonport: Tasmanian Weed Society, 1999a. p. 592-595. Available in: <www.caws.org.au/awc/1996/awc199614891.pdf> Access on: May, $08^{\text {th }}, 2011$.

MULLETT, T. L. Ecological aspects of sweet pittosporum (Pittosporum undulatum Vent.): implications for control and management. In: BISHOP, A.C.; BOERSMA, M.; BARNES, C.D. Proceedings of the 12th Australian Weeds Conference. Devonport: Tasmanian Weed Society, 1999b. p.489-492. Available in: : < (ww.caws.org.au/ awc/1996/awc199614891.pdf) > Access on May, $08^{\text {th }}, 2011$.

NACHTIGAL, G.F. Controle biológico de plantas invasoras exóticas no Sul do Brasil por meio de fitopatógenos: princípios e estratégias de aplicação em ecossistemas agrícolas e naturais. Pelotas: Embrapa Clima Temperado, 2009. 49p.

OLIVEIRA, M. A. S. P.; BORBA, A. E. S. Estudo do valor nutritivo do incenso (Pittosporum undulatum Vent.) e da sua influência sobre a fermentação do rúmen. Revista de Ciências Agrárias, v.22, n.4, p.27-36, 1999.

PAIVA, P. Pittosporum. In: S. Castroviejo (ed.). Flora Iberica - Plantas vasculares de la Península Ibérica e Islas Baleares. v. 5 Ebenaceae - Saxifragaceae. Madrid: Real Jardín Botânico, 1997. pp. 1-73.

PARANÁ. Secretaria de Estado do Meio Ambiente. Instituto Ambiental do Paraná. Portaria IAP n⿳074, de 19 de abril de 2007. Lista Oficial de Espécies Exóticas Invasoras para o Estado do Paraná.
PIMENTEL， D.; MCNAIR, S.; JANECKA, J.; WIGHTMAN, J.; SIMMONDS, C.; O'CONNELL, C.; WONG, E.; RUSSEL, L.; ZERN, J.; AQUINO, T.; TSOMONDO, T. Economic and environmental threats of alien plant, animal, and microbe invasions Agriculture, Ecosystems and Environment, v. 84, p. 1-20, 2001.

PLANTAS DO FUTURO, 2003. Available in: : <www. pfaf.org $>$ Access on May, $08^{\text {th }}, 2011$.

ROSE, S. Influence of suburban edges on invasion of Pittosporum undulatum into the bushland of northern Sydney, Australia. Australian Journal of Ecology, v. 22, n. 1, p. 89-99, 1997.

SANTA CATARINA. Secretaria de Estado do Desenvolvimento Econômico Sustentável. Conselho Estadual do Meio Ambiente. Resolução CONSEMA N ${ }^{\circ}$ 11, de 17 de dezembro de 2010. Lista Oficial de Espécies Exóticas Invasoras no Estado de Santa Catarina.

SANTANA, O. A.; ENCINAS, J. I. Levantamento das espécies exóticas arbóreas e seu impacto nas espécies nativas em áreas adjacentes a depósitos de resíduos domiciliares. Biotemas, v. 21, n. 4, p. 29-38, 2008.

SECRETARIADO DA CONVENÇÃO SOBRE DIVERSIDADE BIOLÓGICA (CBD). Panorama da Biodiversidade Global 3. Brasília: Ministério do Meio Ambiente, Secretaria de Biodiversidade e Florestas (MMA), 2010. 94 p.

TROPICOS Missouri Botanical Garden. Available in: $<$ www.tropicos.irg> Access on May, 16 ${ }^{\text {th }}, 2011$.

TUNBRIDGE, A.; SIMMONS, D.; ADAMS, R. Allelopathic effects of sweet Pittosporum (Pittosporum undulatum Vent.) on the germination of selected native plant species. The Victorian Naturalist, v. 117, n. 2. p. 44-50, 2000.

USDA Database for the proanthocyanidin content of selected foods - 2004 Available in: <http://www.nal. usda.gov/fnic/foodcomp/Data/PA/PA.html $>$ Access on: September, $22^{\text {nd }}, 2011$.

WALKER, B.; STEFFEN, W. An overview of the implications of global change for natural and managed terrestrial ecosystems. Conservation Ecology, v.1, n.2, p. 10-25, 1997. Available in <http://www.consecol.org/voll/ iss2/art2/>. Access on May, 08 ${ }^{\text {th }}, 2011$. 